\title{
Tipps und Tricks: Kugelkopfschraubenzieher
}

\author{
$\square$ Dankward Höntzsch
}

Schraubenzieher mit kugeligem Kopf erlauben es, dass eine Schraube auch leicht abgewinkelt eingebracht und entfernt werden kann.

Dies ist bei Schrauben am Ende oder in der Tiefe und in sonstigen Positionen sehr hilfreich. Sehr hilfreich ist dieser Kugelkopfschraubenzieher bei Metallentfernungen durch Stichinzisionen.

Der Kugelkopf findet viel leichter in den Inbus ${ }^{\circledR}$. Er hat auch keine so große Stempelwirkung, sodass er etwaige noch einliegende Weichteile herausschiebt.
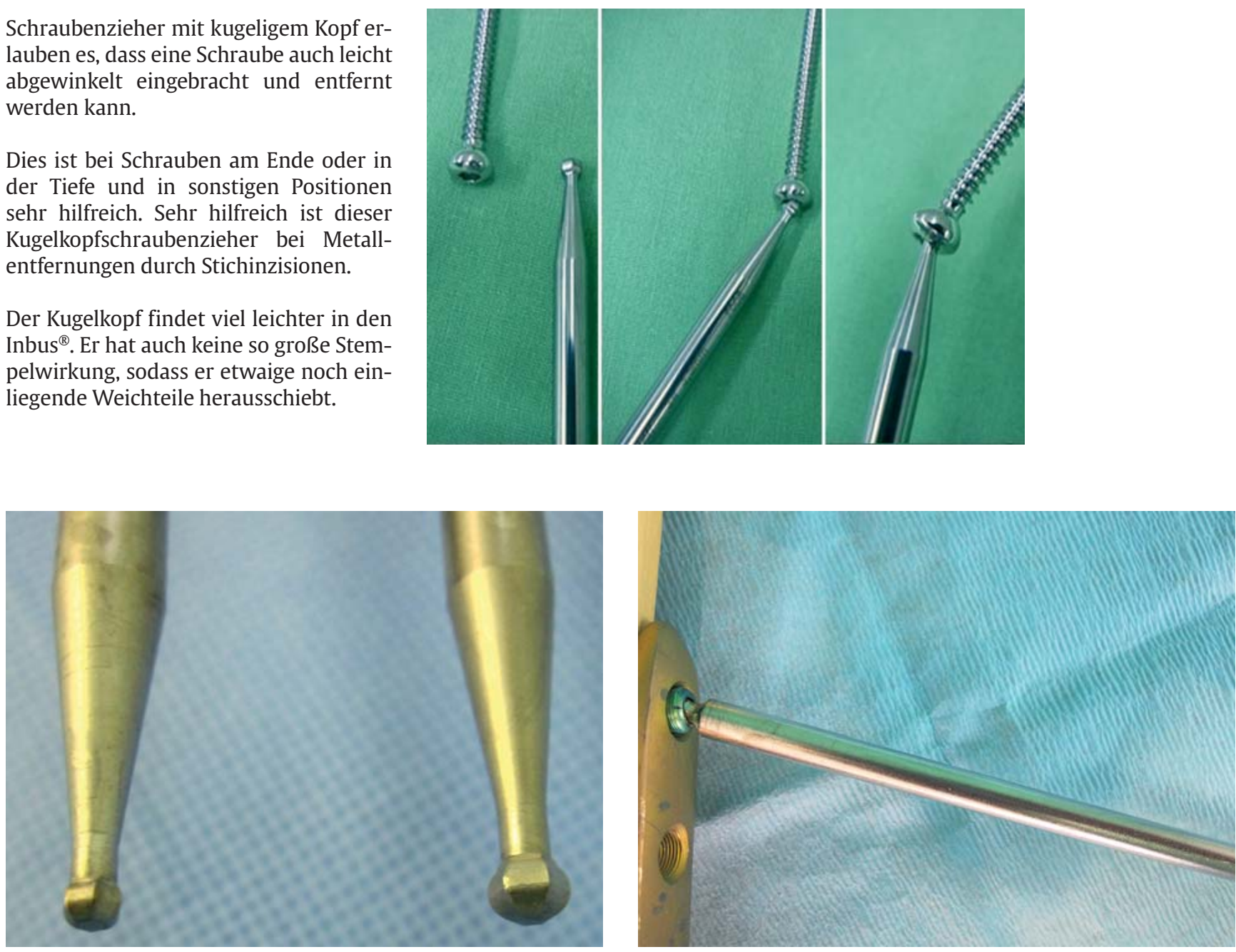